\begin{abstract}
ポテンショスッタットから眺める電気化学分析法の特色.
2. ポテンショスタットの電源.
\end{abstract}

\author{
片野 肇 \\ A technical note concerned with potentiostat. \\ 2. Power supply for potentiostat.
}

\title{
Hajime KATANO
}

Most potentiostats require dual regulated DC power supply, which supplies e.g. $+15 \mathrm{~V}$ and $-15 \mathrm{~V}$. In this technical note, we will consider such power supplies. Linear regulated type and switched-mode type power DC supplies for potentiostat are compared with each other. Also, an example of the USB (universal serial bus) powered potentiostat is described.

1 ポテンショスタットの電源の要件

ボルタンメトリー実験では印加電位を正 電位から負電位の領域に渡って規制するこ とがあるし，電流も正電流だけでなく負電 流を測定する. そのため, ポテンショスタッ トを動かすための電源としては，図2-1に示 すような $+V_{\mathrm{s}}, 0,-V_{\mathrm{s}}$ の 2 電源 3 出力のものが 必要になる。

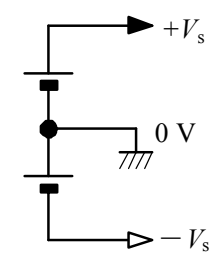

図2-1 3 出力 2 電源

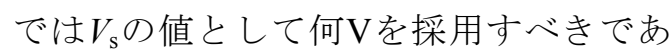
ろう.まずはOPアンプの規格から考えると, 前稿図1-16の回路で選んだOP-07（実際は同 等品である新日本無線NJMOP07D）の場合， 3〜 $18 \mathrm{~V}$ と公称されるように広い電源電圧 範囲で用いることができる。

福井県立大学生物資源学部（广910-1195 福井 県吉田郡永平寺町松岡兼定島 4-1-1) Fuculty of Bioscience, Fukui Prefectural University (Eiheiji, Fukui 910-1195, Japan)
次に, 電気化学測定法の見地からポテン ショスタットが扱う電圧を考える。印加電 位 $(E)$ は, OPアンプの電源電圧範囲の下限で ある土3 Vもあればたいていの試験で事足り るであろう。Eは参照極のターミナル電位 $\left(E_{\mathrm{RE}}\right)$ に対する作用極のターミナル電位 $\left(E_{\mathrm{WE}}\right)$ であるが, $E_{\mathrm{WE}}$ が仮想接地 $\left(E_{\mathrm{WE}}=0\right)$ され るポテンショスタットを考えれば， $E_{\mathrm{RE}}(=$ $-E) も \pm 3 \mathrm{~V}$ 範囲となる。この電圧はボル テージフォロワを構成するOPアンプの非反 転入力に印加される. 先に記したようにOP アンプの入力電圧は電源電圧を超えてはな らないので, $V_{\mathrm{s}}>3 \mathrm{~V}$ はこの要件を満たすこ とになる。

対極のターミナル電位 $\left(E_{\mathrm{CE}}\right)$ は先に示した ように複雑な挙動を示すが，簡単のため $E_{\mathrm{CE}}$ の絶対值は $E$ と同程度, すなわち, $\pm 3 \mathrm{~V}$ 範 囲にあると仮定する。対極のターミナルは カレントアンプを構成するOPアンプの出力 に繋がっており, OPアンプの出力電圧もま た電源電圧を超えてはならないことから， $V_{\mathrm{s}}>3 \mathrm{~V}$ はこの要件を満たすことになる.こ の点からも $V_{\mathrm{s}}$ は $3 \mathrm{~V} よ も$ 高ければ良いこと になる。

このようにポテンショスタットの電源電 圧は, 本質的には高い值を要求しない。し かしながら，電源に関するモジュール・電 


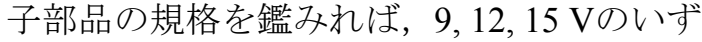
れかを選ぶのが得策である。

次に，消費電流について触れてみたい. ここでは前稿図1-16のポテンショスタット の消費電流を図2-2のような方法で実測して みた。

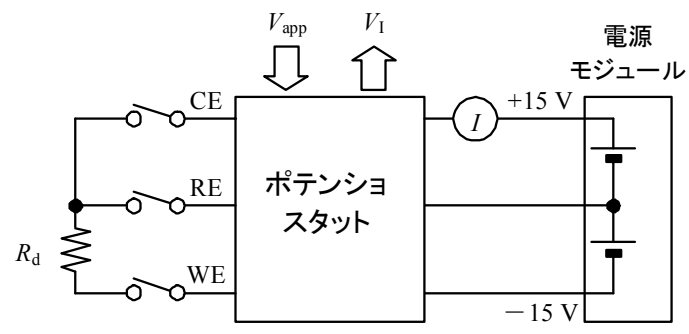

困2-2 ポテンショスタットの消費電流測定

ここでは，入力電圧 $\left(V_{\text {app }}\right)$, すなわち， $E$ を1 Vとした。電解セルの代わりに $100,1 \mathrm{k}$, $10 \mathrm{k} \Omega$ の抵抗を接続し，10,1,0.1 mA負荷時 ないしは無負荷時にポテンショスタットの 電源ラインに流れる電流を測定したところ, 無負荷では7.2 mAの電流值が示された。こ の值については，無負荷時でもOPアンプが 消費する電流によると見なせる（ちなみに， ここで採用した新日本無線NJMOP-07の標 準值は2.7 mAであり, 本ポテンショスタッ トではこれを 3 石用いている). 次に $0.1 \mathrm{~mA}$,

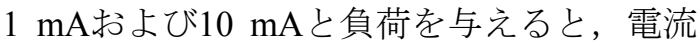
值はそれぞれ,7.2, 8.1および16.8 $\mathrm{mA}$ とっ た. $-15 \mathrm{~V}$ 電源ラインについてもほぼ等し い值が得られた。この結果より，図1-16のポ テンショスタットの消費電流はおおむねOP アンプの消費電流と試験電極に流れる電流 の和で与えられるとみなせる.OP-07および その同等品は比較的消費電流の大きいOPア ンプであり，これを小電流のものに換える などできるが，いずれにしても，以下では， ポテンショスタットの消費電流は10 mA程 度とする。

以上より，電源電圧を $\pm 15 \mathrm{~V}$ とても，ポ テンショスタットの消費電力は $0.3 \mathrm{~W}$ 程度 である。いくつかの紫外可視吸光光度計の
消費電力の公称值が数十Wであることを鑑 みれば，消費電力が低いことも電気化学測 定の利点の一つと言えるだろう。では，ポ テンショスタットの電源として具体的にど のようなものが使えるのだろうか.

\section{2 ポテンショスタットの電源}

\section{1 電池の使用}

OP-07を含め汎用OPアンプの多くは $9 \mathrm{~V}$ でも動作するので, 9 Vの角型乾電池を図2-1 のように 2 個使うことを考えてみよう。そ もそも，9Vの角型乾電池は高い電圧を必要 とする一方, 消費電力は小さい用途に用い られる。この電池の容量を $300 \mathrm{mAh} と$ (こ の值は使用状況などで変わるため, 公称值 が見当たらない），ポテンショスタットの 消費電流をおよそ10 mAとすれば， $300 \mathrm{mAh}$ $\div 10 \mathrm{~mA}=30$ 時間は使用できることになる. 乾電池は後述するリプル成分を含まない優 れた直流電源であるし，装置のポータビリ ティの点でも好ましいが，その交換を常に 気にしなければいけないために，常時電源 として用いるのは現実的ではなかろう。

2.2 非安定化直流電源と簡易 $\mathrm{AC}$ アダプタ

本来電池でも動く電化製品を実際はACア ダプタで駆動する事は多い。ここでは図2-3 の回路で構成される簡易 ACアダプタを例と して，交流の直流化について触れたい。今 時の携帯電話に用いられる平べったい・小 型のものでなく, 古くから用いられる結構 重たいACアダプタとお考えいただきたい.

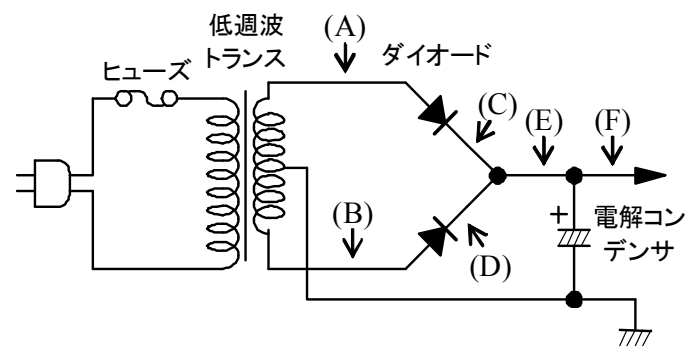

図2-3 非安定化直流電源（単電源） 
まずトランスは100 Vの交流を任意の電 圧に変えて伝達するものである。図2-3では 出力側のセンタータップが接地されており

（以下，この電位を基準とする），図2-3中

（A）および(B)の電圧の時間変化は，図2-4 中AおよびBに示すように振幅は同じだが反 転した関係となる。
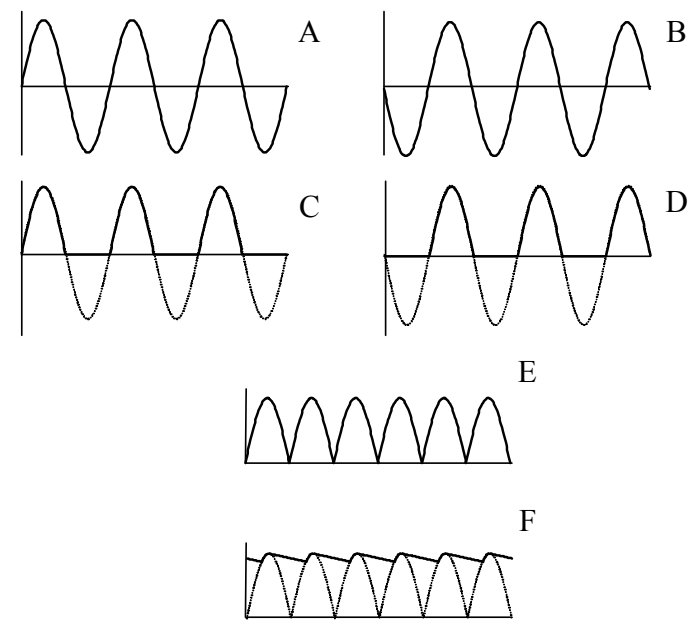

図2-4 図2-3の各位置における電圧波形。た だしC, D, Eは図2-3中それぞれの位置より右 の回路がないとした場合

次に, ダイオードは矢印の方向にのみ電 流を流す素子であり，図2-3の(C)および(D) の電圧の波形は（これより右の結線がなけ れば），それぞれ図2-4のCおよびDのように なる。次にCとDを結んだ場合，すなわち 点は，これより右のコンデンサが無ければ, それらが加算されたものとして図2-4Eのよ うになる。この電圧変化をコンデンサによ り平滑化するが，どれだけ平滑化できるか は周波数（の高さ）とコンデンサの容量に 依る。商用電源の周波数は50/60 Hzと低く, 比較的容量の大きいコンデンサでも十分な 平滑化はできず, 図2-4中Fのような脈流とな る.

なお都合上，ここで，負電圧を含めた 3 出力電源を得る方法について触れておくと, 図2-5のようにダイオード 2 とコンデンサ
を加えることで, 図2-4中CおよびDの点線部 分の電圧を負電圧の電源として利用できる.

図2-4中Fのような直流電源の電圧変動は リプルと呼ばれる。原則的には，リプルは OPアンプの，すなわち測定装置のノイズの 原因となるため，このような非安定化直流 電源をそのままポテンショスタットの電源 として用いるのは好ましくない。しかしな がら，ACアダプタを電源とする測定機器は 多いし，ACアダプタを用いず，電源コンセ ントにより商用電源を用いる装置でも図2-3 ないしは図2-5の回路が含まれる場合が多い. そうした装置の中では, 図2-4中Fのような脈 流電圧を安定な直流電圧の電源に変換して いるわけであるが，その方法としてドロッ パ方式とスイッチング方式が挙げられる ${ }^{1)}$.

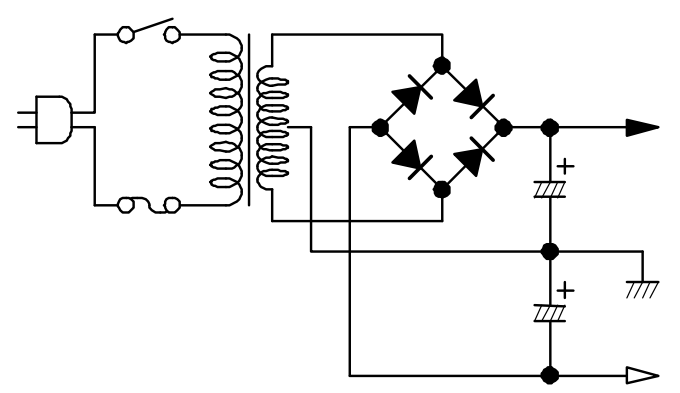

図2-5 非安定化直流電源 ( 3 出力 2 電源源)

2.3 ドロッパ方式安定化電源

ドロッパ方式安定化電源の原理を図2-6a に示す．非安定化電源（この電圧を $V_{\text {in }}$ とす る）に可変抵抗 $(R)$ と負荷を直列に繋いだ ものと等価とお考えいただきたい，消費す る電流をIとすれば，負荷に与えられる電源 電圧 $\left(V_{\mathrm{s}}\right)$ は， $V_{\mathrm{s}}=V_{\text {in }}-I R$ となるが，この $V_{\mathrm{s}}$ が常に所定の電圧となるように $R$ を制御 するという原理である。

$R$ の制御はトランジスタ, ツェナーダイ オードなどから成る回路で構成できるが, 消費電流が 1 A以下であれば 3 端子レギュ レータという素子の利用が得策である。こ の素子は図2-6bに示すように 3 本のピンが 出ている集積回路で，外見はトランジスタ 
とほぼ同じである。3 端子レギュレータに は正電圧用と負電圧用ものがあって，数字 の型番がそれぞれ78および79で始まる。ま た，5，9，12，15 Vと何Vを出力するかが決 まっていて，その值が先の数字に続く.す なわち, +5 Vなら 7805, -12 Vなら7612 と いった具合である。

a )

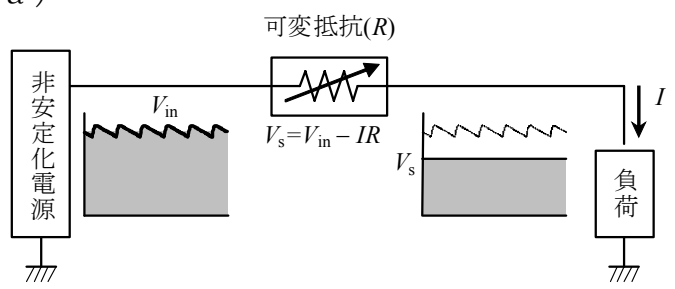

b )
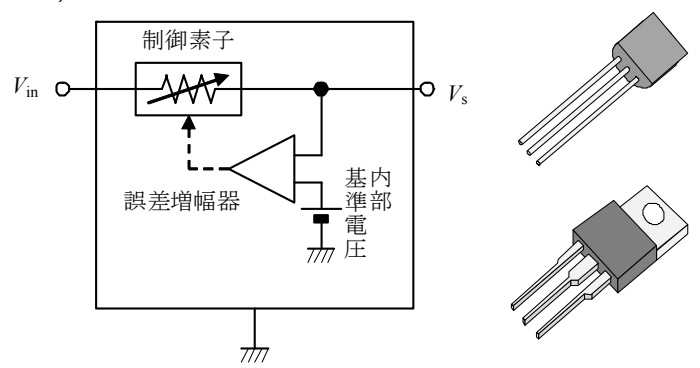

困2-6 a ）ドロッパ方式安定化電源の原理 と b ）３端子レギュレータ

その使用法として，図2-5の非安定化電源 より $\pm 15 \mathrm{~V}$ 得る回路を図2-7に示す。C1は 発振防止を目的とするものであって，3 端 子レギュレータの近くに配線する。 $\mathrm{D}_{1}, \mathrm{D}_{2}$ のダイオードは破損を防ぐためのものであ る(なお， $\mathrm{D}_{2}$ はショットキバリアダイオー ドと呼ばれるもので，通常のダイオードと は記号が少し異なる）。

ドロッパ方式による安定化直流電源はリ ニア電源などとも呼ばれる。後述のスイッ チング電源に対する利点は，よりリプルが 少ないことであり，一般に測定機器の電源 として推奨される. なお，図2-5および図2-7 のような回路は自作せずとも商用電源から $\pm 15 \mathrm{~V}$ 出力するモジュールが市販されて
いる。しかしながら，後述のスイッチング 電源と比べれば品数は圧倒的に少なく, 高 価である. その理由となる一般的な欠点を 記すと，まず，図2-6の電圧降下分の電力を 熱として捨てることが挙げられる. その分 エネルギー利用効率は下がるし, その電力 量によって放熱板を取り付けなければなら ない。他には, 商用電源を扱うための低周 波トランスを用いることも欠点となる。こ のような低周波を扱うとなると，どうして もある程度の大きさと重さ（および価格） になる．市販のモジュールについて大きさ と重さの例を後に示すが，ポテンショス タットは本質的には小型・軽量といった利 点があるのに，リニア電源を用いるとなる と，その利点は失われてしまうことになる。

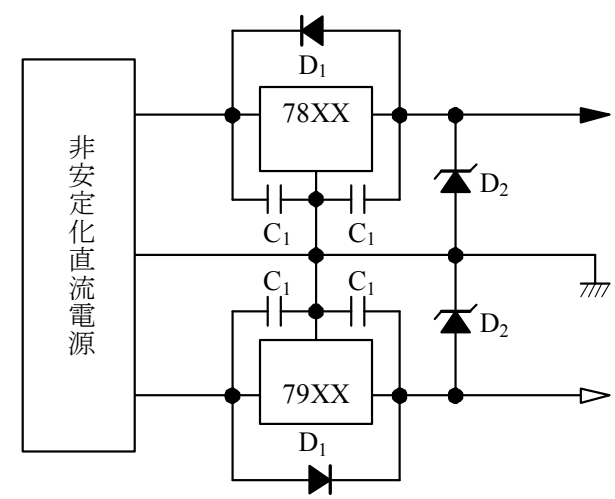

図2-7３端子レギュレータによる安定化電 源回路

2.4 DC-DCコンバータとスイッチング電源 スイッチング方式はDC-DCコンバータ回 路を用いた直流の安定化である。その原理 を図2-8に示す。

同図中のスイッチにて ONーOFFを繰り返 して，非安定化直流電圧を図2-9Aのような パルス状の交流電圧に換える。直流を得よ うとしているのに交流に戻すわけだが，こ のスイッチングでは100 kHz以上の高周波 の交流電源を作ることに意味がある。 


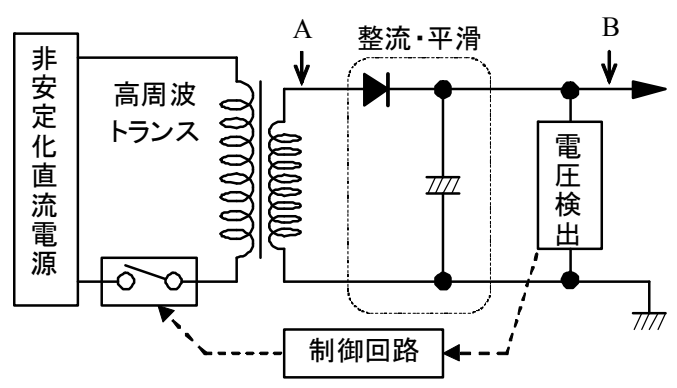

図2-8ＤC-DCコンバータの原理
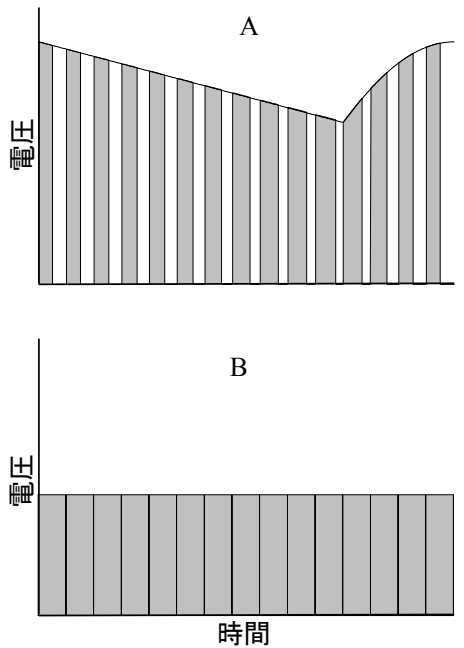

困2-9 困2-8中A,Bの電圧波形の概念図

この交流電圧をダイオードによる整流と コンデンサによる平滑化で直流電圧とする. 図2-3の回路では，50/60 Hzと低周波数の交 流を扱うことから比較的大容量のコンデン サでも平滑化が十分にできないのであって, 高周波なら容量の小さいコンデンサでもあ る程度の平滑化ができる。また，最終的に 出力される電圧はトランスの比率だけでな く, PWF方式 ${ }^{1)}$ 場合はパルス幅にもよる. この方式は, 出力電圧が所定の值となるよ う（図2-9Bの四角形の面積がみな同じにな るよう），図2-9Aのパルス幅を調節するこ とで，所定の電圧の直流電源を得るもので ある。

ここで，図2-8中のトランスの入力電圧は
別に100 Vでも良い。よって，低周波トラン スは使わずに商用電源を直接ダイオードで 整流してもよい。一方，図2-8中のトランス は高周波を扱うものであるため格段に小型 化できる.このため, 電源全体の小型化・ 軽量化が可能となる。さらには, リニア電 源のように電力を熱として捨てることもな く, エネルギー変換効率は高い。一方, ス イッチング電源の大きな欠点は, 実際には 平滑化が十分に行えず，高周波のリプルが 発生することである（文献2にその波形の実 例が見られる）。例えば，後述の市販リ二 ア電源モジュールのリプルは $2 \mathrm{mV}$ pp以下 と公称されるが，スイッチング電源の場合 は典型值が $150 \mathrm{mV} \mathrm{ppである。このため，ス}$ イッチング電源は“一般的には” 測定装置 の電源としては推奨されない.

では，スイッチング電源はポテンショス タットに使えないかというと, そうではな い。まず，高周波リプル除去の対策はいく つかあり ${ }^{1,2)}$ ，中には基板毎およびOPアンプ 毎のバイパスコンデンサ（補足参照）の使 用という，電源リプルの大小に関わらず行 われる対策がある。また，3端子レギュレー タを用いれば，高周波であってもリプルは 除去できるため，次節ではこの方法を採用 している。それよりも，我々は通常の電気 化学測定において100 kHz以上の高周波成 分を扱うことはない。簡単に言えば, $0.1 \mathrm{~ms}$ 以下の時間間隔で電流変化を観察すること はないはずである（例えば, $0.1 \mathrm{~ms}$ 毎に印加 電位を $1 \mathrm{mV}$ 変化させて電流を観察するとし たら，それは $10 \mathrm{~V} / \mathrm{s}$ と超高速の掃引速度での ボルタンメトリーとなる）。ポテンショス タットの応答の時定数はいくつかに決めね ばならないが, 通常はこの值が $10 \mu$ 秒以内で ある必要はなく, $100 \mathrm{kHz}$ のノイズ成分は平 滑化される。さらに言えば，印加電位の制 御と電流信号の記録をコンピュータ制御で 行うのであれば，最終的に得られる信号に はアナログ/デジタル変換モジュールにお ける変換誤差が含まれる。この変換誤差が ポテンショスタットのリプルによるノイズ 
が低いのであればその電源は問われないこ とになる。

ここで，100 Vの交流電源から $\pm 15 \mathrm{~V}$ の直 流を出力する市販のリニア電源モジュール とスイッチング電源モジュールの大きさと 重さを比べてみる。図2-10aはリニア電源の

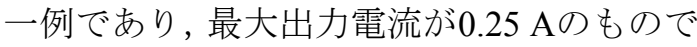
ある. その外形はおよそ7 cm (W) × $10 \mathrm{~cm}$ (D) $\times 7 \mathrm{~cm}(\mathrm{H})$ で重量は700 g程度である。図 2-10bはスイッチング電源の一例であり，最 大出力電流は $0.2 \mathrm{~A}$ と上記リニア電源と同程 度である。その外形はおよそ7 $\mathrm{cm}(\mathrm{W}) \times 10$ $\mathrm{cm}(\mathrm{D}) \times 3 \mathrm{~cm}(\mathrm{H})$ で重量は200 g程度である. 確かに，このスイッチング電源はリニア電 源より $1 / 3$ ほど小型で軽量であるが，その大 きさと重さのいずれもポテンショスタット 本体のそれを上回る.

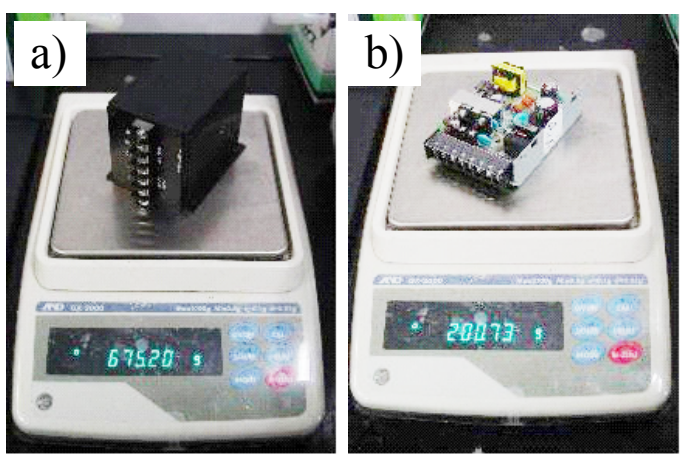

図2-10 市販の(a)リニア電源モジュールと (b)スイッチング電源モジュールの例

そもそも，その最大出力が $6 \mathrm{~W}$ とポテン ショスタット本体の消費電力を遥かに上回 る.これらよりも出力の小さいものを探し てタたが，市販の電源モジュールで，商用 電源から $1 \mathrm{~W}$ 以下の直流電源を出力するも のが見当たらなかった。だいたい，消費電 力が $1 \mathrm{~W}$ に満たない実験装置を商用電源か ら駆動するのは，大げさな事なのではない だろうか。

3 USBからの電源供給

市販のDC-DCコンバータ素子には5 V程度
の単電源を入力し， $\pm 15 \mathrm{~V}$ を出力するものも 見られる。これを利用すれば，円筒型乾電 池 3 個や，簡易 $\mathrm{AC}$ アダプタ 1 個でポテン ショスタットが動かせる.

また，パソコンのUSBポートからは5 Vの 電源が取り出せる. 簡単には図2-11に示すよ うなUSB補助電源ケーブルが利用できる

(その出力プラグはACアダプタと同じ規格 である）。なお，パソコンにアナログ入出 力ボードを用いれば，ファンクションジェ ネータとX-Yレコーダを備えた電気化学測 定システムが構成できる，パソコンをノー 卜型にすれば，商用電源を要さず，どこで もボルタンメトリーができることになる。 このため5 Vの直流電源をポテンショス タットの電源とする試みは興味深い.

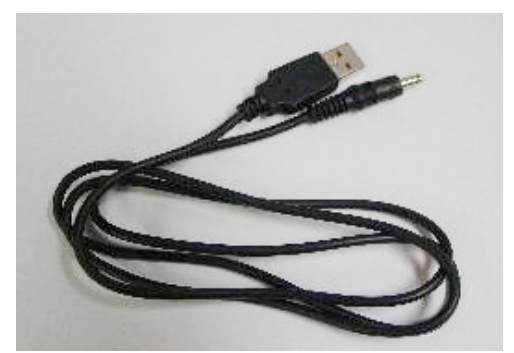

図2-11 USB補助電源ケーブル

ここではDC-DCコンバータ素子として コーセル社のSUW30515を用いるとした。 そ の入力電圧範囲は4.5 9 V と公称され, 出力 電圧は $15 \mathrm{~V}$ である. その最大出力電流は 0.1 Aであり，前述のリニア電源およびスイッチ ング電源モジュールと同程度であるものの, 図2-12の写真a)に示すようにこの素子の外 形は2〜3 $\mathrm{cm}$ 四方で高さは数mmと極めて小 さく，その重さはたった $2 \mathrm{~g}$ 程度である。

具体的な配線図を図2-13に示す. USB補助 電源ケーブルのような5 Vの直流電源のプ ラグに合う規格(EIA2)のDCジャックで受け て, SUW30515に入力する.また, 出力電圧 は土12 Vに降下するが，高周波リプル除去の ために 3 端子レギュレータ7812および7912 を用いるとした。この場合 $3 \mathrm{~V}$ 電圧による 電力を熱として捨てることになるが， 3 端 
子レギュレータ 1 個当たり $0.03 \mathrm{~W}(=3 \mathrm{~V}$ $\times 0.01 \mathrm{~A})$ と低いため放熱板の必要は無い. な お，ポテンショスタットに用いる事を前提 としているため図2-7に記した保護用のダイ オードは設けていないが，これらを実装し ても差し支えない. なお，図2-13の回路を構 成した基板を図2-12bに示す.
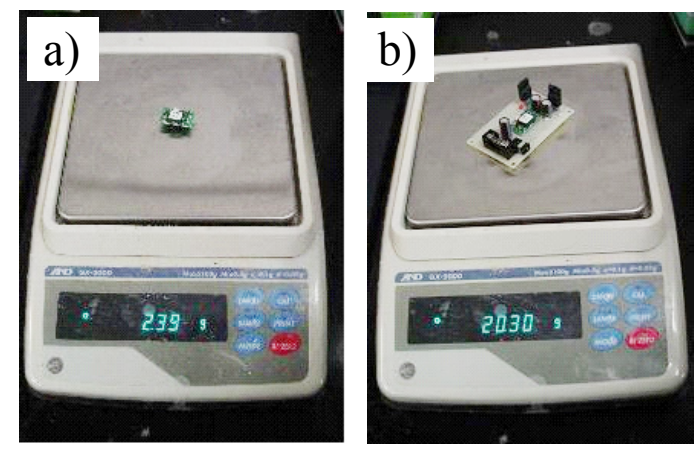

図2-12 a)市販のDC-DCコンバータ回路素 子の例とb)図2-13の回路を構成した基板

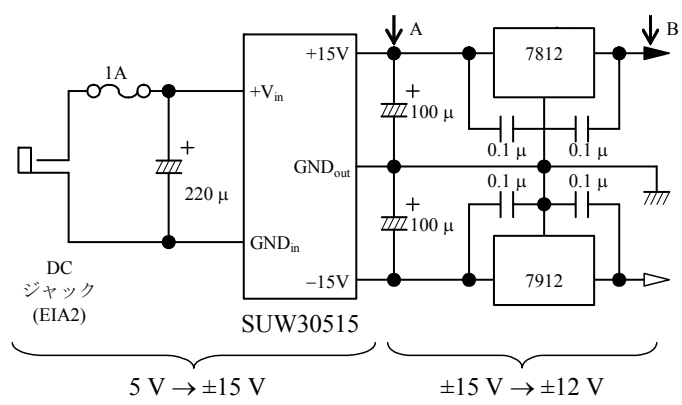

図2-13 $5 \mathrm{~V}$ 前後の電源からポテンショス タット用の $\pm 12 \mathrm{~V}$ を得る電源モジュール

\section{4 ポテンショスタットの電源の違いと} ボルタンメトリー測定システムの雑音

ここで, 図2-10aのリニア電源モジュール， 図2-10bのスイッチング電源, 図2-12 a の D $\mathrm{C}$ - DCコンバータ（詳しくは図2-13の5-15 Vと記した回路），図2-12 b の電源モジュー ルのそれぞれについてリプルの実測は興味 深いが，筆者はそのための測定装置を有し ていない。そもそもリプルは電源を供給す る回路によって変動するし, 重要なのはこ
れら電源の違いが測定結果に及ぼす影響で ある。よって，これら電源をポテンショス タットに用い, 得られる電流信号の雑音の 評価を行うとした。

ここで用いるポテンショスタットは図 1-16の回路を基本とするものであるが，各 OPアンプには $0.1 \mu \mathrm{F}$ のバイパスコンデンサ, 基板には47 $\mu \mathrm{F}$ の高周波平滑用電解コンデン サを用いてある。ここでは電解セルの代わ りに10 $\mathrm{k} \Omega$ の抵抗に対する電流信号を観測 するとした。ポテンショスタットからの ケーブルで本来作用電極に接続するクリッ プを抵抗の足の片方に繫ぎ，参照電極およ び対極に繋ぐ。この抵抗はファラデーケー ジに入れる（図2-14）。また，ポテンショス タットの時定数は $0.001 \mathrm{~ms}$ 選んだ.よって, ポテンショスタット内ではバイパスコンデ ンサのみが電源リプルを減衰させる要素と なる。

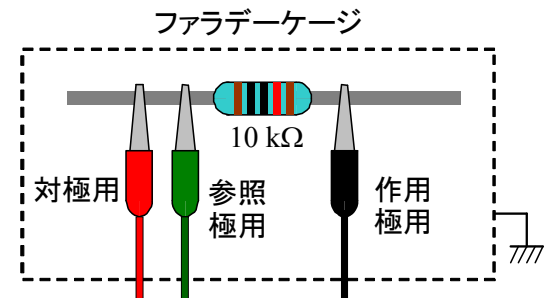

図2-14＼cjkstart実験に用いたダミーセル

ここでは，アナログ入出力ボード（イン タフェース社CSI-360116）を介してコン ピュータ制御により印加電位 $(E)$ を制御し, その結果ダミーセルを流れる電流值を取り 込むとした. Eの制御および電流值のサンプ リングは1 ms間隔で行った。 ポテンショス タットの電源として，まずは図2-12aの DC-DCコンバータ（5 Vの直流電圧はUSB補 助ケーブルを介してコンピュータより与え た）を用い， $V_{\text {app }}=0.000 \mathrm{~V}$ の状態から 1 秒後 に1.000 Vにステップ変化させ, その 1 秒後 に-1.000 Vにステップ変化させ, またその 1

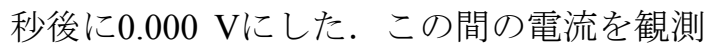


した結果を図2-15に示す.このサンプリング 間隔では, 得られる電流信号はEのステップ 変化に追従していた。また，オームの法則 に従い, $V_{\mathrm{app}}(=E)=0.000 \mathrm{~V}$ では $0 \mu \mathrm{A}, V_{\mathrm{app}}=$ $1.000 \mathrm{~V}$ では $100 \mu \mathrm{A}, V_{\text {app }}=-1.000 \mathrm{~V}$ では $-100 \mu \mathrm{A}$ の電流值が得られた. ポテンショス タットの電源を図2-10aのリニア電源モ ジュール, 図2-10bのスイッチング電源, 困 2-12bの電源モジュールに換えたが，図2-15 と同様の結果が得られた。

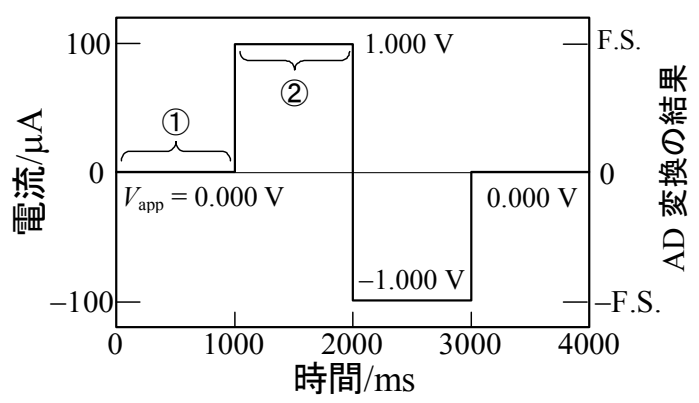

図2-15 ダミーセルを用いた場合の印加電 位 $\left(V_{\text {app }}\right)$ のステップ変化に対するポテンショ スタットの応答

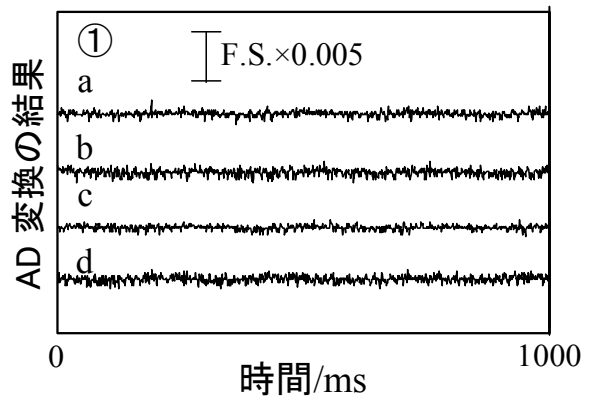

図2-16 図2-15の電流応答において(1)の電 流值を拡大した結果. (a)図2-10aのリニア電 源モジュール，(b) 図2-10bのスイッチング 電源モジュール, (c) 図2-12aのD C - DCユ ンバータ, 図2-12bの電源モジュールを用い た場合

図2-15の電流応答のうち(1)の部分を拡大
したものを図2-16に示す. 雑音の大きさはポ テンショスタットの電源に依らず同程度の 值であった。しかし，この雑音はAD変換部 で生じたものであって, 図2-15(2)の領域で あっても, ダミーセルの抵抗值を $1 \mathrm{k} \sim 1 \mathrm{M} \Omega$ と換えても，ポテンショスタットの電流レ ンジを $10 \mu \mathrm{A} \sim 1 \mathrm{~mA} / \mathrm{V}$ と換えても, ポテン ショスタットの時定数を $0.01 \sim 10 \mathrm{~ms}$ と換え ても $\mathrm{AD}$ 変換器の入力レンジ(F.S.) の \pm 0.0001 程度（図2-15の実験条件では $\pm 0.1 \mu \mathrm{A}$ に対応 する）と変わらない。

要するに, リプルが比較的大きいとされ るスイッチング電源を用いても，ポテン ショスタット内で生じる雑音は極めて小さ く，多くの実験ではこれを用いても差し支 えないとみなせる。なお，上述したように ダミーセルに $1 \mathrm{k} \Omega$ の抵抗を用いた場合, 観 察される雑音は $\pm 10 \mathrm{nA}(= \pm 0.001 \times 10 \mu \mathrm{A})$ で あったが, この雑音も $\mathrm{AD}$ 変換部で生じたも のであるため，作用極一参照極のターミナ ル間の電位制御は $\pm 10 \mu \mathrm{V}(= \pm 10 \mathrm{nA} \times 1 \mathrm{k} \Omega)$ よ りも高い精度で行えていることになる.

以上より，スイッチング電源ないしは DC-DCコンバータもポテンショスタットに 適用できると言える。その消費電力の見 合った電源を用いることで，小型・軽量で あるというポテンショスタット本来の利点 が具現化されるであろう。さらに，ポテン ショスタットをUSBバスパワーにより駆動 するとし，ここで用いたCSI-360116のような カード型アナログ入出力インターフェース を介してノート型パソコンにより $V_{\mathrm{app}}$ の制 御と $V_{\mathrm{I}}$ の記録をするとすれば, 商用電源を用 いず持ち運びが容易なボルタンメトリー測 定システムが可能となる。最近ではそのよ うな実製品も存在しており, 電気分析化学 法の特色の一つに, 消費電力が小さいため 装置のポータビリティに優れる点が挙げら れるであろう。

\section{5 文献}

1) 日本テキサス・インスツルメンツ社著 “低電圧時代の電源ICクックブック”， CQ出版社. 
2) 高野慶一, 石井聡, 道場俊平, 栗林良太, 松井邦彦，“今寸ぐ使えるパソコン計測 USBマイコン基板”, CQ出版社.

補足 バイパスコンデンサ

図2-13の電源であれ，リニア電源であれ， スイッチング電源モジュールであれ，その 出力は何かの回路に用いられる。ここでは ポテンショスタット本体部分を構成した基 板に出力するわけであるが, 図2-17に示すよ うに，基板に配線したすぐ傍にコンデンサ を接続しなければならない。この理由は, ごく簡単に言うと, 電源一基板間の配線で 雑音が混入する, すなわち, リプルが生じ てしまうのだが，これを平滑化するためで ある。この用途で用いるコンデンサをバイ パスコンデンサと呼ぶ. その $\mathrm{C}_{1}$ は通常 $47 \mu \mathrm{F}$ 程度のものが用いられるが，タンタルコン デンサや高周波平滑用（低インピーダンス） の電解コンデンサが望ましい. $\mathrm{C}_{2}$ は $\mathrm{C}_{1}$ と並 列であることから一見意味が無いように思 えるが，コンデンサの種類による周波数特 性の違いのために必要であって $0.1 \mu \mathrm{F}$ 程度 のセラミックコンデンサを用いる.

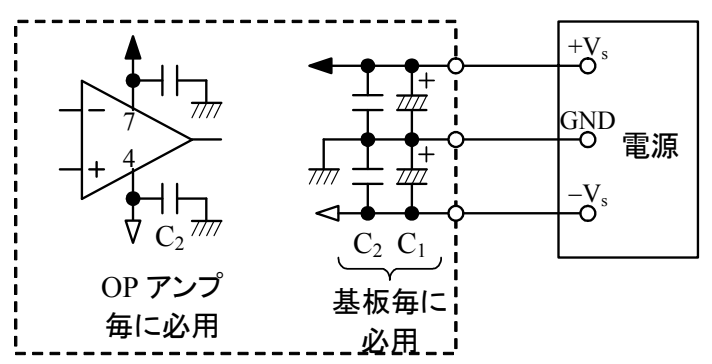

困2-17 バイパスコンデンサ

なお，基板上で，OPアンプの電源につい ても配線にいくぶんの長さがある以上，バ イパスコンデンサを必用とする.この場合， OPアンプの電源入力部，OP-07などの場合7 番と4番ピンの近くに $0.1 \mu \mathrm{F}$ 程度のセラミッ クコンデンサを接続する。 バイパスコンデ ンサは必須のものであるため通常配線図で は記さない事が多い. 